\title{
VACCINATION AGAINST INFLUENZA: ATTITUDE OF HEALTH CARE PERSONNEL IN A MULTIDISCIPLINARY HOSPITAL IN LATVIA
}

\author{
Ludmila Vīksna $^{1,2}$ Mārtiṇš Vilcāns ${ }^{2}$, Indra Zeltiṇa ${ }^{1,2}$, Aija Leidere-Reine ${ }^{1,3}$, \\ Angelika Krūmiṇa $^{1,2}$, Oksana Koḷesova $^{4}$, Jeḷena L̦eviṇa ${ }^{5}$, and Aleksandrs Koḷesovs ${ }^{6}$ \\ ${ }^{1}$ Department of Infectology and Dermatology, Rīga Stradiṇš University, 3 Linezera Str., Rīga, LV-1006, LATVIA \\ ${ }^{2}$ Clinical Centre "Gaiḷezers", Rīga Eastern Clinical University Hospital, 2 Hipokrāta Str., Rīga, LV-1038, LATVIA \\ ${ }^{3}$ Latvian Centre of Infectious Diseases, Rīga Eastern Clinical University Hospital, 3 Linezera Str., Rīga, LV-1006, LATVIA \\ 4 Joint Laboratory of Clinical Immunology and Immunogenetics, Rīga Stradiṇš University, 5 Rātsupītes Str., Rīga, LV-1067, LATVIA \\ ${ }^{5}$ Latvian Prison Administration, 89 Stabu Str., Rīga, LV-1009, LATVIA \\ ${ }^{6}$ Department of Psychology, University of Latvia, 1 Imantas $7^{\text {th }}$ line, Rĩga, LATVIA \\ \# Corresponding author, oksana-kolesova@inbox.Iv
}

Contributed by Ludmila Vīksna

\begin{abstract}
Health care personnel (HCP) are at high risk of acquiring influenza due to exposure to patients. However, vaccination in HCP is lower than $40 \%$ for most European countries. The aim of this study was to determine the attitude towards influenza vaccination and possible reasons for this attitude in HCP. A cross-sectional study was performed in a multidisciplinary hospital of Latvia. The sample $(n=1099)$ included doctors (239), nurses (418), care services (236), administrative staff (108), and technical support staff (98). Five questions addressed vaccination of planned patients and HCP, knowledge of etiological anti-influenza drugs, and their storage at the hospital for immediate use. The results revealed that the level of regular vaccination against influenza in $\mathrm{HCP}$ was relatively low (14\%). This contrasted with a more positive attitude towards vaccination of patients (53\%) and personnel (60\%). This contrast provided evidence for a low level of proactive action. High expectations regarding medications covered by the hospital (82\%) indicated transferring of part of personal responsibility to the organisation. Doctors demonstrated a better understanding of the problem and a higher level of vaccination. However, some of doctors' attitudes showed underestimation of influenza-associated risk.
\end{abstract}

Key words: influenza, vaccination, attitude, primary control, secondary control.

Influenza is among the most common highly contagious infectious diseases, which results in the death of hundreds of thousands of people annually (Palache et al., 2015). Defined as any person working in a health care setting (Pearson at al., 2006; Shefer et al., 2011), health care personnel (HCP) are at high risk of acquiring influenza virus infection due to exposure to the patients, infectious materials, or contaminated air. At the same time, unvaccinated HCP might be the source of infection for patients and contribute to nosocomial influenza outbreaks in health care settings. These outbreaks lead to increased patient morbidity and mortality, HCP illness and absenteeism, and economic costs to the health care system (Stewart and Cox, 2013).
Vaccination is the most effective way to prevent this infection. The World Health Organisation recommends that $75 \%$ of the HCP should be vaccinated against influenza. However, vaccination in the HCP group is lower than $40 \%$ for most European countries (Jorgensen et al., 2018), and the decline in influenza vaccination coverage among HCP is an international problem (Hulo et al., 2017). The common reasons for the low vaccination rate include fear of sideeffects, inadequate knowledge about influenza and vaccination, lack of perceived risk of influenza infection, concerns over vaccine safety and effectiveness, lack of free time for vaccination, and unavailability or high costs of vaccine (Cozza et al., 2015; To et al., 2016; Hulo et al., 2017; 
James et al., 2017). An important factor for vaccine hesitancy in Europe is also a reported mismatch between circulating and vaccine strains (Cozza et al., 2015; Hulo et al., 2017). Being vaccinated relates positively to a higher knowledge score based on epidemiological influenza items (Hulo et al., 2017).

Based on data of the Disease Prevention and Control Centre of Latvia, about 240 people in Latvia died because of influenza complications in the last three years (Anonymous, 2018). The average age of these patients was 60-70 years. Despite regular information provided to the public, no more than $2.5 \%$ of the population of Latvia are vaccinated against influenza every year (Anonymous, 2018). The state compensates $50 \%$ costs of the vaccine for pregnant women, elderly individuals (aged more than 65 years), and individuals with chronic medical conditions, while children 6-24 months and particular health groups of children and adolescents 24 months -18 years have $100 \%$ compensation. In the 2017/2018 season, 23534 people used state compensated vaccines (Anonymous, 2018).

The Disease Prevention and Control Centre of Latvia recommends vaccination against influenza for all HCP, but it is not mandatory. The aim of this study was to determine the attitude towards influenza vaccination and possible reasons for this attitude in HCP of a multidisciplinary hospital of Latvia.

From a psychological perspective, attitudes towards and decisions regarding vaccination involve the use of selfregulatory control strategies (Heckhausen et al., 2010). Primary control means changing the situation through direct action (e.g., vaccination). Secondary control includes a change in individual expectations regarding possible outcomes (e.g., lowering the perceived probability of a disease). Therefore, primary control associates with proactive acting before the possible problem, while secondary control facilitates reactive acting after the problem occurs. In addition to primary and secondary modes of control, selective and compensatory control presents individual use of personal and external resources, respectively. In the case of vaccination, the involvement of external resources means sharing responsibility for personal health with others (e.g., health care organisation).

The study was approved by the Ethics Committee of Rīga Stradiňš University. A cross-sectional study started in November 2016 and finished in March 2017. This study period included the epidemic influenza season of 2016-2017 in Latvia (Anonymous, 2017). The survey was conducted in a multidisciplinary hospital of Latvia with staff of more than 4380. The participation was voluntary and anonymous. About 1300 respondents answered the questions, and 1099 answers were valid. The participants were doctors (239), nurses (418), care services (236), as well as administrative staff (108), and technical support staff (98).

The following questions were posed:
1. Do you support that planned patients who are being admitted to treatment during an influenza epidemic should be vaccinated against influenza?

2. Do you support that health care personnel should be vaccinated against influenza because they represent a risk group?

3. Have you been vaccinated against influenza every season?

If you checked "No", please answer two additional questions:

Would you be willing to be vaccinated against influenza?

a. if the vaccine would be available with a $50 \%$ discount?

b. if the vaccine would be free of charge $(100 \%$ discount)?

4. Do you know any etiological influenza medications and how to take them when you start getting sick?

5. In your opinion would it be useful to have reserves of influenza medications in the hospital in case you become ill at the workplace, as then you could start to take medications immediately (at the expense of the hospital) and further continuing to take them at your own expense?

Statistical analysis of the answers was performed by IBM SPSS Statistics 22.0 for Windows. The chi-square test was applied for a comparison of the level of agreement or disagreement to a particular question. McNemar's chi-square test for related samples was used for a paired comparison of answers to different questions.

Table 1 presents the proportions of positive answers to the questions regarding different aspects of vaccination. A comparison of answers in the sample demonstrated that a positive attitude towards vaccination of medical personnel at risk $(60 \%)$ was higher than the positive attitude towards vaccination of planned patients $(53 \%)$, McNemar's $\chi^{2}(1)=$ $18.22, p<0.001$. However, the percentage of regularly vaccinated HCP (14\%) was about four times lower (Fig. 1) than the assessed need for vaccination of patients (53\%), McNemar's $\chi^{2}(1)=377.13, p<0.001$, and HCP at risk $(60 \%)$, McNemar's $\chi^{2}(1)=483.56, p<0.001$. Doctors had relatively higher regular vaccinations $(27 \%), \chi^{2}(1)=44.91$, $p<0.001$, and positive attitude towards vaccination of the personnel at risk (70\% of agreement), $\chi^{2}(1)=12.54, p<$ 0.001 , than other groups of HCP. The doctors' attitude towards vaccination of planned patients was similar to that of other groups, $\chi^{2}(1)=2.70, p=0.101$.

Not-vaccinated HCP had a relatively negative attitude towards vaccination with $50 \%$ cost discount (15\% of agreement), $\chi^{2}(1)=410.16, p<0.001$, while their attitude towards vaccination for free ( $48 \%$ of agreement) did not significantly differ from the $50 \%$ compensation, $\chi^{2}(1)=$ $2.49, p=0.114$. 
ABSOLUTE FREQUENCY AND PERCENTAGE OF A POSITIVE ATTITUDE TOWARDS ASPECTS OF VACCINATION IN FIVE SUBSAMPLES AND IN THE TOTAL SAMPLE $(\mathrm{n}=1099)$

\begin{tabular}{|c|c|c|c|c|c|c|}
\hline Question & $\begin{array}{c}\text { AD } \\
(\mathrm{n}=108) \mathrm{f}(\%)\end{array}$ & $\begin{array}{c}\text { CS } \\
(n=236) f(\%)\end{array}$ & $\begin{array}{c}D \\
(n=239) f(\%)\end{array}$ & $\begin{array}{c}\mathrm{N} \\
(\mathrm{n}=418) \mathrm{f}(\%)\end{array}$ & $\begin{array}{c}\text { TS } \\
(n=98) \mathrm{f}(\%)\end{array}$ & $\begin{array}{c}\text { Total sample } \\
\mathrm{f}(\%)\end{array}$ \\
\hline 1. Vaccination of planned patients & $41(38 \%)$ & $127(54 \%)$ & $138(58 \%)$ & $234(56 \%)$ & $45(45 \%)$ & $585(53 \%)$ \\
\hline 2. Vaccination of medical personnel & $64(59 \%)$ & $140(59 \%)$ & $167(70 \%)$ & $227(54 \%)$ & $58(59 \%)$ & $656(60 \%)$ \\
\hline 3. Regular personal vaccination & $3(3 \%)$ & $22(9 \%)$ & $65(27 \%)$ & $54(13 \%)$ & $10(10 \%)$ & $154(14 \%)$ \\
\hline 3a. Vaccination (50\% discount) & $10 / 91(11 \%)$ & $23 / 179(13 \%)$ & $35 / 161(22 \%)$ & $43 / 318(14 \%)$ & $10 / 80(13 \%)$ & $121 / 829(15 \%)$ \\
\hline 3b. Vaccination (100\% discount) & $46 / 104(44 \%)$ & $113 / 221(51 \%)$ & $93 / 186(50 \%)$ & $166 / 369(45 \%)$ & $44 / 91(48 \%)$ & $462 / 971(48 \%)$ \\
\hline 4. Knowledge of etiological drugs & $60(56 \%)$ & $149(63 \%)$ & $222(93 \%)$ & $350(84 \%)$ & $36(37 \%)$ & $817(74 \%)$ \\
\hline 5. Storage of covered drugs & $82(76 \%)$ & $183(78 \%)$ & $199(83 \%)$ & $357(85 \%)$ & $81(83 \%)$ & $902(82 \%)$ \\
\hline
\end{tabular}

AD, Administrative staff; CS, Care services; D, Doctors; N, Nurses; TS, Technical support personnel; f, absolute frequency of positive answers. Answers to Questions $3 \mathrm{a}$ and $3 \mathrm{~b}$ show the frequency of positive attitude and the number of answers (f/n) because the questions were not obligatory for vaccinated employees and were omitted by some participants.

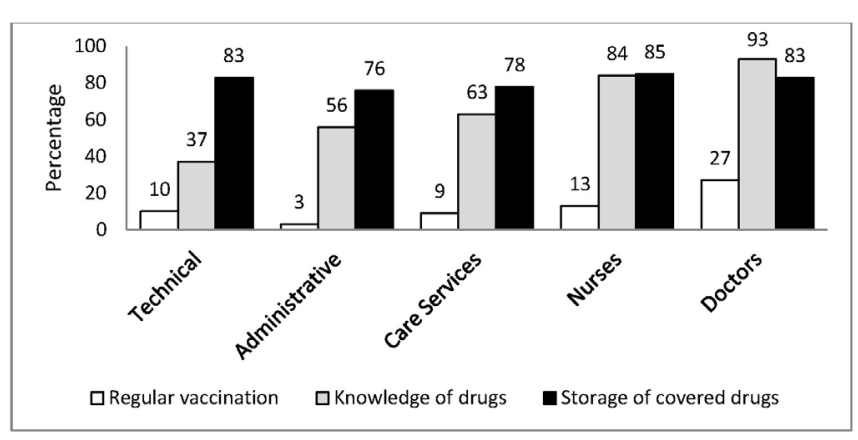

Fig. 1. Percentage of regular vaccination of personnel and attitude towards etiological drugs.

The most positive attitude was towards storing anti-influenza medication, the cost of which would be covered by the hospital (82\% of agreement), $\chi^{2}(1)=449.69, p<0.001$. In addition, the total sample demonstrated relatively high knowledge (74\% of agreement) on etiological anti-influenza drugs, $\chi^{2}(1)=254.63, p<0.001$. Doctors had better knowledge on etiological drugs $(93 \%), \chi^{2}(1)=53.84, p<0.001$, and had similar attitudes as other groups in the attitude towards employer covered drugs, $\chi^{2}(1)=0.15, p=0.695$.

In general, the level of vaccinated HCP was relatively low (14\%) and remained much lower than $75 \%$, the rate recommended by WHO. For comparison, similar levels of vaccinated HCP were described in hospitals in Italy (Cozza et al., 2015), Croatia, Switzerland, and Serbia (Jorgensen et al., 2018). In contrast, the highest level of vaccination was under the mandatory vaccination policy in the United States (up to 96\%) (Black et al., 2015), Belarus (95\%), Albania (90\%), and Armenia (100\%) (Jorgensen et al., 2018).

Doctors demonstrated a better understanding of the danger of infection spread and were vaccinated more often than other groups of HCP. This concurs with other studies on vaccination of HCP (Hulo et al., 2017; Hagemeister et al., 2018). However, about one-third of doctors in our study did not consider that the risk group should be vaccinated, and about two-fifths of doctors did not expect vaccination of planned patients.
The comparisons of attitudes revealed significant differences in the assessment of the need for vaccination for patients and HCP and actual behavior regarding regular vaccination. The results demonstrated a gap between the general attitude towards the usefulness of vaccination and riskprevention behavior. Possible explanations of the differences include lowering the personal risk of disease and relatively high reliance on aetiological medication in the case of influenza. In accordance with views of self-regulatory control (Heckhausen et al., 2010), changing expectations regarding disease (secondary control) seems to be a more powerful regulatory strategy in HCP than personal vaccination (primary control). In addition to differences in primary and secondary control, the preference for compensatory control is apparent as the difference between the level of vaccination $(14 \%)$, based on personal resources including time, effort, and finances, and the level of expected support from the hospital in the case of infection (82\%). It can also show a misbalance in taking personal responsibility and transferring it to the hospital (employer).

The percentage of vaccinated HCP in the hospital was higher than in the population of Latvia. At the level of the population, it amounted to $1.10 \%$ in 2016-2017 (Anonymous, 2017) and 2.24\% in 2017-2018 (Anonymous, 2018). Despite a relatively higher level of vaccination in HCP, prophylaxis of nosocomial outbreak in hospitals should be developed in Latvia. Solving the problem by discounting vaccination costs remains in question. In the case of a possible $50 \%$ discount, the general attitude remained relatively negative, while an imagined $100 \%$ discount increased the rate of positive answers no more than to the fifty-fifty level.

Another solution is balancing relatively high expectations regarding the hospital and personal responsibility for vaccination. On the one hand, personal responsibility should be clearly stated. For example, mandatory vaccination for HCP can be considered, as it has been discussed in European countries (Maltezou and Poland, 2014). On the other hand, administration of the vaccine at the workplace contributes to the level of vaccination (Hagemeister et al., 2018). Therefore, hospitals can organise vaccination on site. 
The main limitation of the study concerns the sample involving HCP of one multidisciplinary hospital in Latvia. The participation was voluntary, and the sample included about one-fourth of HCP of the hospital. Opinions of motivated participants can indicate negative or positive tendencies, but a more precise assessment of views of HCP in Latvia remains in question. In addition, data did not include the age and gender of HCP, which can differ regarding attitude towards vaccination (Hagemeister et al., 2018). Therefore, further studies require the inclusion of a more representative randomised sample. A more detailed analysis of types of attitudes is needed for a better understanding of possibilities to facilitate vaccination against influenza.

The level of vaccination against influenza in HCP was relatively low, which contrasted with a more positive general attitude towards vaccination of patients and HCP at risk. This contrast provided evidence for preferring reactive rather than proactive actions regarding influenza. High expectations of support from the hospital indicated transferring of some part of personal responsibility to the organisation. Doctors demonstrated better understanding of the dangers involved and had a higher level of vaccination. However, some aspects of doctors' attitudes indicated underestimation of influenza-associated risk.

\section{REFERENCES}

Anonymous (2017). Slimību profilakses un kontroles centrs. Pārskats par saslimstību ar akūtām augšējo elpceḷu infekcijām (AAEI) un gripu 2016.-2017. gada epidēmiskajā sezonā. [Center for Disease Prevention and Control. Overview of acute upper respiratory tract infections and influenza during the epidemic season 2016-2017] (in Latvian). Available from: https://www.spkc.gov.1v/upload/Datu\%20bazes/gripa_2016_2017_ sezona_1.pdf (accessed 15 May 2019).

Anonymous (2018). Slimību profilakses un kontroles centrs. Pārskats par saslimstību ar akūtām augšējo elpceḷu infekcijām (AAEI) un gripu 2017.-2018. gada epidēmiskajā sezonā. [Center for Disease Prevention and Control. Overview of acute upper respiratory tract infections and influenza during the epidemic season 2017-2018] (in Latvian). Available from: https://www.spkc.gov.1v/upload/Infekcijas\%20slim\%C4\% ABbas/ Bileteni/2018.gads/09.2018./eb_gripa_aaei_2017_2018_sezona.pdf (accessed 15 May 2019).

Black, C. L., Yue, X., Ball, S. W., Donahue, S. M. A., Izrael, D., de Perio, M. A., Laney, A. S., Williams, W. W., Lindley, M. C., Graitcer, S. B., Lu, P., Bridges, C. B., DiSogra, C., Sokolowski, J., Walker, D. K., Greby, S. M.
(2015). Influenza vaccination coverage among health care personnel United States, 2014-15 influenza season. MMWR Morb. Mortal Wkly Rep., 64 (36), 993-999.

Cozza, V., Alfonsi, V., Rota, M. C., Paolini, V., Atti, M. L. C. (2015). Promotion of influenza vaccination among health care workers: Findings from a tertiary care children's hospital in Italy. BMC Public Health, 15, 697.

Hagemeister, M. H., Stock, N. K., Ludwig, T., Heuschmann, P., Vogel, U. (2018). Self-reported influenza vaccination rates and attitudes towards vaccination among health care workers: Results of a survey in a German university hospital. Public Health, 154, 102-109.

Heckhausen, J., Wrosch, C., Schulz, R. (2010). A motivational theory of life-span development. Psychol. Rev., 117, 32-60.

Hulo, S., Nuvoli, A., Sobaszek, A., Salembier-trichard, A. (2017). Knowledge and attitudes towards influenza vaccination of health care workers in emergency services. Vaccine, 35, 205-207.

James, P. B., Rehman, I. U., Bah, A. J., Lahai, M., Cole, C. P., Khan, T. M. (2017). An assessment of healthcare professionals' knowledge about and attitude towards influenza vaccination in Freetown Sierra Leone: A crosssectional study. BMC Public Health, 17, 692.

Jorgensen, P., Mereckiene, J., Cotter, S., Johansen, K., Tsolova, S., Brown, C. (2018). How close are countries of the WHO European Region to achieving the goal of vaccinating $75 \%$ of key risk groups against influenza? Results from national surveys on seasonal influenza vaccination programmes, 2008/2009 to 2014/2015. Vaccine, 36, 442-452.

Maltezou, H. C., Poland, G. A. (2014). Vaccination policies for healthcare workers in Europe. Vaccine, 32, 4876-4880.

Palache, A., Oriol-Mathieu, V., Fino, M., Xydia-Charmanta, M., on behalf of the influenza vaccine supply task force (IFPMA IVS) (2015). Seasonal influenza vaccine dose distribution in 195 countries (2004-2013): Little progress in estimated global vaccination coverage. Vaccine, 33, 5598-5605.

Pearson, M. L., Bridges, C. B., Harper, S. A. (2006). Influenza Vaccination of Health-Care Personnel Recommendations of the Healthcare Infection Control Practices Advisory Committee (HICPAC) and the Advisory Committee on Immunization Practices (ACIP). MMWR Recomm. Rep., 55 (2), $1-20$.

Shefer, A., Atkinson, W., Friedman, C., Kuhar, D. T., Mootrey, G., Bialek, S. R., Cohn, A., Fiore, A., Grohskopf, L., Liang, J. L., Lorick, S. A., Marin, M., Mintz, E., Murphy, T. V., Newton, A., Fiebelkorn, A. P., Seward, J., Wallace, G. (2011). Immunization of health-care personnel: Recommendations of the advisory committee on immunization practices (ACIP). MMWR Recomm. Rep., 60 (7), 1-45.

Stewart, A. M., Cox, M. A. (2013). State law and influenza vaccination of health care personnel. Vaccine, 31, 827-832.

To, K. W., Lai, A., Lee, K. C. K., Koh, D., Lee, S. S. (2016). Increasing the coverage of influenza vaccination in healthcare workers: Review of challenges and solutions. J. Hospital Infect., 94, 133-142.

Received 28 December 2018

Accepted in the final form 23 May 2019

\section{VAKCINĀCIJA PRET GRIPU: VESELĪBAS APRŪPES PERSONĀLA ATTIEKSME LATVIJAS DAUDZNOZARU SLIMNĪCĀ}

Veselības aprūpes personāls (VAP) ir pakḷauts augstam gripas riskam, jo regulāri kontaktējas ar pacientiem, tai skaitā, gripas. Tomēr lielākajā daḷā Eiropas valstu VAP vakcinēts pret gripu mazāk par 40\%. Ši pētījuma mērkis bija noteikt VAP attieksmi pret vakcināciju pret gripu un analizēt iespējamos šīs attieksmes iemeslus. Šķērsgriezuma pētījums tika veikts vienā no Latvijas daudznozaru slimnīcām. Izlasē (n = 1099) bija iekḷauti ārsti (239), medmāsas (418), aprūpes personāls (236), administrācija (108) un tehniskā atbalsta personāls (98). Tika uzdoti pieci jautājumi par plānoto pacientu un VAP vakcināciju, zināšanām par pretvīrusu zālēm un to rezervju veidošanas nepieciešamību slimnīcā tūlītējai lietošanai. Rezultāti atklāja, ka VAP regulārās vakcinācijas līmenis bija salīdzinoši zems (14\%) un būtiski nesaskanēja viedokḷi, ka vakcinācija nepieciešama pacientiem (53\%) un personālam (60\%). Šis kontrasts liecināja par zemu VAP proaktīvas rīcības līmeni. Savukārt lielas cerības attiecībā uz zālēm, kuras varētu nodrošināt slimnīca (82\%), liecināja par daḷēju personīgās atbildības nodošanu organizācijai. Kopumā ārsti parādīja labāku izpratni par problēmas izpratni un augstāku personīgas vakcinācijas līmeni nekā citi darbinieki. Tomēr dažas pozīcijas ārstu attieksmē pret vakcināciju pret gripu liecina, ka saistîtais risks ir nepietiekami novērtēts. 